\title{
Profil Komunikasi Matematika Tulis Siswa SMP dalam Memecahkan Masalah Matematika Ditinjau dari Kepribadian Extrovert dan Introvert
}

\author{
Dwi Permatasari ${ }^{{ }^{*}}$, Rini Setianingsih ${ }^{1}$ \\ ${ }^{1}$ Program Studi Pendidikan Matematika, Universitas Negeri Surabaya \\ *Corresponding Author: dwipermata99@gmail.com
}

\begin{tabular}{l} 
ARTICLE INFO \\
\hline Article history: \\
Received 23 Jan 2021 \\
Revised 5 Mar 2021 \\
Accepted 25 May 2021 \\
Keywords: \\
Mathematical \\
communication; \\
Extrovert-introvert \\
personality
\end{tabular}

\begin{abstract}
Communication is important in mathematics learning. This study aims to describe the written mathematics communication profile of junior high school students in solving mathematics problems reviewed from extrovertintrovert personality. The subjects of this study consist of one introvert student and one extrovert student, while the instruments used were the Myers Briggs Type Indicators personality questionnaire, math ability tests, and written mathematics communication tests. The results of this study revealed that introvert student fulfilled the accuracy and completeness aspect at the stage of understanding the problems, devising a plan, and carrying out the plan. Meanwhile, the extrovert students fulfill the accuracy aspect only at the stage of understanding the problem. Besides that, extrovert students fulfill the completeness aspect at the stage of carrying out the plan and looking back. Introvert and extrovert students do not fulfill the fluency aspect. So that introvert students' written mathematics communication is better than extrovert students.
\end{abstract}

(C) 2021 The Author(s) Published by JRPM (Jurnal Review Pembelajaran Matematika) This is an open access article under CC BY-SA license (https:// creativecommons.org/licenses/by-sa/4.0/)

\section{How to cite:}

Permatasari, D \& Setianingsih, R. (2021). Profil Komunikasi Matematika Tulis Siswa SMP dalam Memecahkan Masalah Matematika Ditinjau dari Kepribadian Extrovert dan Introvert. JRPM (Jurnal Review Pembelajaran Matematika), 6(1), 1-12

\section{PENDAHULUAN}

Komunikasi menjadi salah satu keterampilan yang diperlukan di abad 21. Komunikasi berperan penting dalam berbagai bidang, tak terkecuali dalam pembelajaran matematika. Siswa mampu menggambarkan serta mengklarifikasi gagasan mereka, pengetahuan mereka tentang hubungan matematis, dan argumen matematis mereka melalui komunikasi matematika (Ontario Ministry of Education, 2005). Lebih lanjut lagi, siswa dapat mengungkapkan gagasan, pendapat, maupun pengetahuannya kepada guru dan temantemannya melalui komunikasi matematika (NCTM, 2000).

Komunikasi matematika sangat penting pada pembelajaran matematika, khususnya 
dalam pemecahan masalah (Kurnila, Jau, Fedi, \& Kurniawan, 2018). Akan tetapi realitas yang ada menunjukkan bahwa kemampuan komunikasi matematika siswa tergolong rendah. Sebagaimana diungkapkan oleh Izzati dan Suryadi (2010) bahwa penguasaan komunikasi matematika bagi siswa tergolong rendah, hal ini dikarenakan pembelajaran matematika selama ini kurang memperhatikan komunikasi matematika.

Komunikasi matematika terdiri dari komunikasi tulis dan komunikasi lisan. Menurut Mahmudi (2009) komunikasi tertulis dapat menggunakan kata-kata, gambar, tabel, dan sebagainya yang menjelaskan proses berpikir siswa, sedangkan komunikasi lisan dapat dilakukan dengan menyampaikan dan menjelaskan ide-ide matematika secara lisan. Penelitian ini lebih fokus ke komunikasi matematika tulis.

Asmana (2018) menyatakan bahwa terdapat tiga aspek yang dapat diamati dari komunikasi matematika tertulis yaitu keakuratan, kelengkapan, dan kelancaran. Keakuratan komunikasi matematika tertulis adalah jika siswa menyampaikan informasi dengan benar sesuai dengan kaidah matematika. Kelengkapan komunikasi matematika tertulis adalah jika siswa menyampaikan informasi secara cukup untuk menyelesaikan masalah. Kelancaran komunikasi matematika tertulis adalah jika siswa menyampaikan informasi dari awal sampai akhir berdasarkan batas waktu yang telah ditentukan (Asmana, 2018).

Komunikasi matematika tulis saling berhubungan dengan pemecahan masalah. Komunikasi matematika tulis dapat berupa ulasan pemecahan masalah yang telah dilakukan oleh siswa. Sebagaimana menurut Mahmudi (2009) komunikasi tertulis dapat berupa deskripsi pemecahan masalah ataupun pembuktian matematika yang menjelaskan keterampilan siswa dalam mengorganisasi berbagai konsep untuk menyelesaikan masalah.

Pemecahan masalah matematika merupakan usaha untuk mencari penyelesaian dari masalah matematika. Sebagaimana diungkapkan oleh Siswono (2008) pemecahan masalah merupakan usaha yang dilakukan seseorang untuk menyelesaikansuatu permasalahan ketika jalan keluar atau jawaban belum terlihat jelas. Polya (1973) menyatakan bahwa langkahlangkah dalam memecahkan masalah diantaranya yaitu: (1) memahami masalah; (2) membuat rencana; (3) melaksanakan rencana; (4) memeriksa kembali.

Siswa yang satu dengan yang lain memiliki perbedaan dan karakteristik tersendiri dalam menyelesaikan masalah matematika. Perbedaan dalam menyelesaikan masalah tersebut dapat disebabkan oleh perbedaan tipe kepribadian siswa. Noviani (2016) menyatakan bahwa perbedaan kepribadian extrovert dan introvert pada setiap individu memiliki peranan penting saat memecahkan masalah. 
Kepribadian dibagi menjadi dua yaitu kepribadian extrovert dan introvert (Suryabrata, 2011). Individu berkepribadian extrovert dipengaruhi dunia objektif yaitu dunia yang berasal dari luar dirinya. Individu yang berkepribadian introvert dipengaruhi dunia subjektif yaitu dunia yang berasal dari dalam dirinya sendiri (Suryabrata, 2011). Menurut Lester D. Crow dan Alice Crow (dalam Susanti, 2016) karakteristik orang extrovert adalah fasih dalam berbicara, sedangkan orang introvert memiliki karakteristik lebih baik tulis menulis daripada berbicara. Lebih lanjut menurut Jazuli dan Lathifah (2018), individu dengan kepribadian extrovert saat mengerjakan sesuatu biasanya dilakukan dengan cepat walaupun tidak sempurna dan kadang bertindak ceroboh, sedangkan individu yang introvert saat mengerjakan sesuatu dilakukan dengan teliti dan hati-hati.

Penelitian tentang komunikasi berdasarkan kepribadian sudah pernah dilakukan oleh Septiana, Kusmayati, dan Fitriana (2018) dengan subjek siswa SMA dan materi program linear. Hasilnya yaitu siswa introvert dapat menyusun dugaan, membuat argumen, dan merumuskan definisi generalisasi. Namun, mereka mengalami kesulitan dalam memahami presentasi matematika. Sementara siswa extrovert dapat mengeksplorasi ide-ide mereka, tetapi mereka kesulitan dalam mengungkapkan ide atau paragraf matematika dalam bahasa mereka. Terdapat juga penelitian dari Satriawan, Budiyono, dan Indriati (2019) dengan subjek siswa SMK dan materi Sistem Persamaan Linear Dua Variabel (SPLDV). Perbedaan penelitian ini dengan penelitian terdahulu yaitu pada penelitian ini mendeskripsikan komunikasi matematika tulis dalam memecahkan masalah berdasarkan kepribadian siswa yang dilihat dari keakuratan, kelengkapan, dan kelancarannya. Perbedaan lainnya yaitu subjek penelitian, penelitian ini subjeknya siswa SMP sedangkan penelitian sebelumnya subjeknya siswa SMA dan SMK. Selain itu terdapat perbedaan materi, pada penelitian ini menggunakan materi Pola Bilangan. Pola bilangan merupakan materi kelas VIII SMP yang memungkinkan siswa mengkomunikasikan hasil pikirannya secara tertulis. Sebagaimana menurut Swasti, Maimunah, \& Roza (2020), Pola dan Barisan Bilangan merupakan materi yang mengharuskan siswa untuk mengkomunikasikan kemampuan komunikasi matematis dengan cara menyampaikan gagasan/pemikiran secara tertulis dengan tepat. Berdasarkan uraian di atas, penulis melakukan penelitian yang bertujuan untuk mendeskripsikan komunikasi matematika tulis siswa SMP berkepribadian extrovert dan introvert dalam memecahkan masalah matematika. 


\section{METODE PENELITIAN}

Penelitian ini merupakan penelitian deskriptif dengan pendekatan kualitatif. Penelitian ini dilakukan secara online di UPT SMPN 5 Gresik. Subjek pada penelitian ini terdiri dari 2 orang yaitu 1 orang berkepribadian extrovert (SE) dan 1 orang berkepribadian introvert (SI) yang memiliki jenis kelamin yang sama dengan kemampuan matematika yang setara. Instrumen pada penelitian ini ada 2 yaitu instrumen utama dan pendukung. Peneliti sebagai instrumen utama, sedangkan instrumen pendukungnya yaitu angket kepribadian Myers Briggs Type Indicators (MBTI), Tes Kemampuan Matematika (TKM), dan Tes Komunikasi Matematika Tulis (TKMT). Angket MBTI digunakan untuk menggolongkan kepribadian siswa termasuk introvert atau extrovert. TKM digunakan untuk mengetahui dan menggolongkan kemampuan matematika siswa. Sedangkan TKMT untuk mendeskripsikan profil komunikasi matematika tulis siswa. Teknik pengumpulan data dengan pemberian angket kepribadian MBTI dan tes, tes terdiri dari 2 yaitu TKM dan TKMT. Selanjutnya data yang diperoleh dianalisis menurut Miles, Huberman, \& Saldana (2014) yaitu kondensasi data, penyajian data, dan penarikan kesimpulan. Untuk mengetahui komunikasi matematika tulis maka dibutuhkan indikator komunikasi matematika tertulis yang diadaptasi dari Asmana (2018) yang disajikan pada Tabel 1.

Tabel 1. Indikator Komunikasi Matematika Tertulis

\begin{tabular}{|c|c|c|}
\hline $\begin{array}{l}\text { Aspek TKMT } \\
\text { yang diamati }\end{array}$ & $\begin{array}{l}\text { Langkah-langkah } \\
\text { Polya }\end{array}$ & Informasi yang disampaikan \\
\hline \multirow[t]{5}{*}{ Keakuratan } & 1. Memahami masalah & $\begin{array}{l}\text { Dapat menuliskan dengan benar hal-hal yang diketahui dan } \\
\text { ditanya. }\end{array}$ \\
\hline & 2. Membuat rencana & $\begin{array}{l}\text { Menyatakan gambar (jika ada) ke dalam bahasa, simbol, ide, atau } \\
\text { model matematika dengan benar yang relevan dengan } \\
\text { permasalahan. }\end{array}$ \\
\hline & & Menuliskan aturan dengan benar sesuai kaidah matematika. \\
\hline & $\begin{array}{l}\text { 3. Melaksanakan } \\
\text { rencana }\end{array}$ & Dapat menuliskan dengan benar langkah-langkah perhitungan. \\
\hline & 4. Memeriksa kembali & Dapat menuliskan dengan benar suatu kesimpulan. \\
\hline \multirow[t]{5}{*}{ Kelengkapan } & 1. Memahami masalah & $\begin{array}{l}\text { Menuliskan hal-hal yang diketahui dan ditanya pada soal cukup } \\
\text { untuk menyelesaikan masalah. }\end{array}$ \\
\hline & 2. Membuat rencana & $\begin{array}{l}\text { Menyatakan gambar (jika ada) ke dalam bahasa, simbol, ide, atau } \\
\text { model matematika yang dibutuhkan cukup untuk menyelesaikan } \\
\text { masalah. }\end{array}$ \\
\hline & & $\begin{array}{l}\text { Menuliskan aturan yang digunakan cukup untuk menyelesaikan } \\
\text { masalah. }\end{array}$ \\
\hline & $\begin{array}{l}\text { 3. Melaksanakan } \\
\text { rencana }\end{array}$ & $\begin{array}{l}\text { Menuliskan langkah-langkah perhitungan yang dibutuhkan } \\
\text { cukup untuk menyelesaikan masalah. }\end{array}$ \\
\hline & 4. Memeriksa kembali & Menuliskan kesimpulan cukup untuk menyelesaikan masalah. \\
\hline
\end{tabular}


Tabel 1. Indikator Komunikasi Matematika Tertulis (Lanjutan)

\begin{tabular}{|c|c|c|}
\hline $\begin{array}{l}\text { Aspek TKMT } \\
\text { yang diamati }\end{array}$ & $\begin{array}{l}\text { Langkah-langkah } \\
\text { Polya }\end{array}$ & Informasi yang disampaikan \\
\hline \multirow[t]{5}{*}{ Kelancaran } & 1. Memahami masalah & $\begin{array}{l}\text { Menuliskan ha-hal yang diketahui dan ditanya dengan tidak ada } \\
\text { coretan koreksian kesalahan }\end{array}$ \\
\hline & 2. Membuat rencana & $\begin{array}{l}\text { Menyatakan gambar (jika ada) ke dalam bahasa, simbol, ide, atau } \\
\text { model matematika dengan tidak ada coretan koreksian kesalahan }\end{array}$ \\
\hline & & $\begin{array}{l}\text { Menuliskan aturan dengan tidak ada coretan koreksian } \\
\text { kesalahan. }\end{array}$ \\
\hline & $\begin{array}{l}\text { 3. Melaksanakan } \\
\text { rencana }\end{array}$ & $\begin{array}{l}\text { Melakukan langkah-langkah perhitungan dengan tidak ada } \\
\text { coretan koreksian kesalahan }\end{array}$ \\
\hline & 4. Memeriksa kembali & $\begin{array}{l}\text { Menuliskan kesimpulan dengan tidak ada coretan koreksian } \\
\text { kesalahan }\end{array}$ \\
\hline
\end{tabular}

Indikator komunikasi matematika tulis poin c pada tahap membuat rencana untuk setiap aspek TKMT yang diamati diubah, awalnya yaitu membuat gambar diganti menjadi menyatakan gambar ke dalam bahasa, simbol, ide, atau model matematika. Hal ini dilakukan karena menginterpretasi gambar menjadi kata-kata, simbol, atau model matematika merupakan salah satu bentuk komunikasi matematika. Sebagaimana dinyatakan Sumarmo (2012) bahwa menyatakan suatu situasi, gambar, diagram, atau benda nyata ke dalam bahasa, simbol, ide, atau model matematik merupakan salah satu kegiatan komunikasi. Selain itu pada aspek kelancaran penelitian ini tidak menggunakan informasi yang disampaikan berdasarkan batas waktu yang telah ditetapkan tetapi menggunakan tidak ada coretan kesalahan. Hal ini dilakukan karena tidak akan dapat mengamati waktu pengerjaan pertahap pemecahan masalah karena proses pengumpulan jawaban dilakukan pada akhir bukan pertiap tahap.

\section{HASIL DAN PEMBAHASAN}

Berikut ini disajikan profil komunikasi matematika tulis siswa berkepribadian introvert dan extrovert.

\section{Profil Komunikasi Matematika Tulis pada Subjek Introvert (SI)}

\section{Memahami masalah}

Tahap awal yang dilakukan oleh SI adalah menuliskan hal-hal yang diketahui dan ditanya, seperti pada Gambar 1. 


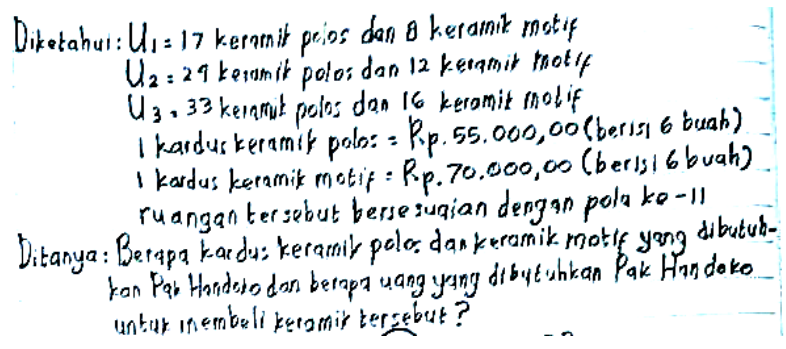

Gambar 1. Lembar jawaban SI pada tahap memahami masalah

Berdasarkan Gambar 1, terlihat bahwa SI menuliskan hal-hal yang diketahui dalam bentuk simbol dan kata-kata. SI menuliskan $U_{1}, U_{2}$, dan $U_{3}$ sebagai pengganti gambar pada pola ke 1, 2, dan 3. Selain itu informasi yang dituliskan yaitu harga keramik polos dan keramik motif per kardus, jumlah keramik dalam satu kardus, serta menuliskan bahwa ruangan bersesuaian dengan pola ke-11. SI juga menuliskan hal-hal yang ditanya dalam bentuk kata-kata dengan benar dan lengkap. Sedangkan untuk aspek kelancaran, SI menuliskan hal-hal yang diketahui dan ditanya secara tidak lancar karena masih terdapat coretan kesalahan. Sehingga dapat dikatakan bahwa dalam memahami masalah SI menuliskan dengan akurat, lengkap, dan tidak lancar. Hal ini sesuai dengan pendapat Satriawan, Budiyono, dan Indriati (2019) bahwa pada tahap memahami masalah subjek berkepribadian introvert menuliskan semua informasi yang dinyatakan secara lengkap dan tepat.

\section{Membuat rencana}

SI mampu membaca gambar dan dapat menyatakan gambar tersebut dalam bentuk barisan, seperti pada Gambar 2.

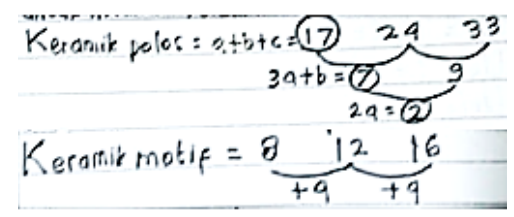

Gambar 2. Lembar jawaban SI tahap membuat rencana

Berdasarkan Gambar 2, terlihat bahwa SI menyatakan jumlah keramik polos dalam bentuk barisan aritmetika bertingkat dimana beda pada barisan tersebut tidak tetap. Sedangkan untuk jumlah keramik motif dinyatakan dalam bentuk barisan aritmetika,dimana barisan tersebut memiliki beda yang selalu sama yaitu +4 . Selanjutnya SI juga menuliskan aturan berupa rumus barisan aritmetika dan barisan aritmetika bertingkat secara tepat, lengkap, dan lancar, sehingga dapat dikatakan bahwa pada tahap merencanakan penyelesaian SI melakukan dengan akurat, lengkap, dan tidak lancar karena ada coretan 
kesalahan.

\section{Melaksanakan rencana}

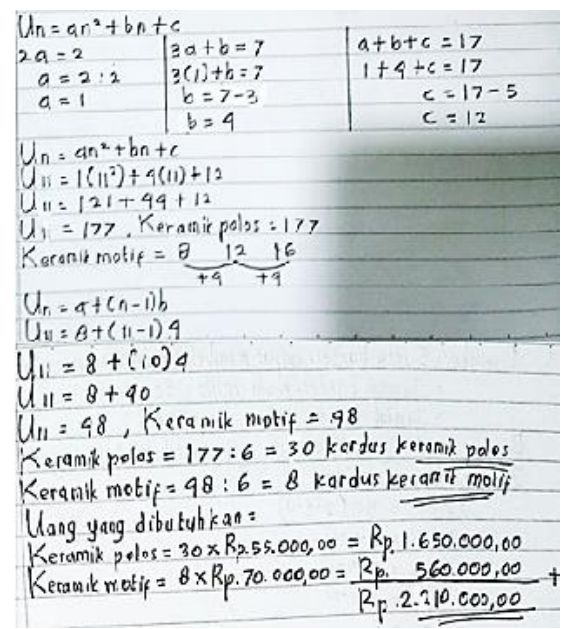

Gambar 3. Lembar jawaban SI tahap melaksanakan rencana

Berdasarkan Gambar 3, terlihat bahwa SI menuliskan langkah-langkah perhitungan dengan runtut, tepat, dan sistematis. Langkah pertama SI menentukan jumlah keramik polos dengan rumus barisan aritmetika bertingkat dan keramik polosnya berjumlah 177 buah, setelah itu menentukan jumlah keramik motif dengan rumus barisan aritmetika dan didapatkan keramik motif sebanyak 48 buah. Langkah selanjutnya SI mencari berapa kardus keramik polos dan keramik motif yang dibutuhkan dengan cara membagi jumlah masing-masing keramik dengan banyaknya keramik dalam satu kardus. Keramik polos yang dibutuhkan yaitu $\frac{177}{6}=30$ kardus, hasil pembagian sebenarnya yaitu 29,5 tetapi karena pada soal dituliskan bahwa pembelian keramik minimal 1 kardus dan tidak boleh mengecer, maka dibulatkan menjadi 30. Keramikmotif yang dibutuhkan $\frac{48}{6}=8$ kardus.

Langkah terakhir yaitu menentukan uang yang dikeluarkan untuk membeli keramik dengan cara mengalikan harga masing-masing keramik dengan jumlah kardus keramik yang dibutuhkan, dan menjumlah antara uang untuk keramik polos dan keramik motif sehingga total uang yang dikeluarkan yaitu Rp2.210.000,00. Sedangkan untuk aspek kelancaran, SI mengomunikasikan dengan kurang lancar karena masih terdapat sedikit coretan kesalahan. Sehingga dapat dikatakan bahwa pada tahap melakukan rencana penyelesaian, SI mengkomunikasikan dengan lengkap, akurat, tetapi tidak lancar. Hal ini sesuai dengan penelitian Satriawan, Budiyono, dan Indriati (2019) bahwa siswa berkepribadian introvert tidak terlalu kesulitan dalam mendeskripsikan langkah-langkah penyelesaiannya. Mereka mampu menjelaskan dan mendeskripsikan perhitungan secara logis dan sistematis. 


\section{Memeriksa kembali}

SI tidak menuliskan kesimpulan dari hasil pemecahan masalahnya, sehingga pada tahap memeriksa kembali dapat dikatakan tidak akurat, tidak lengkap, dan tidak lancar. Sejalan dengan hasil penelitian Septiana, Kusmayati, dan Fitriana (2018) bahwa siswa kepribadian introvert tidak menuliskan hasil akhir atau kesimpulan dari pekerjaannya.

\section{Profil Komunikasi Matematika Tulis pada Subjek Extrovert (SE)}

\section{Memahami masalah}

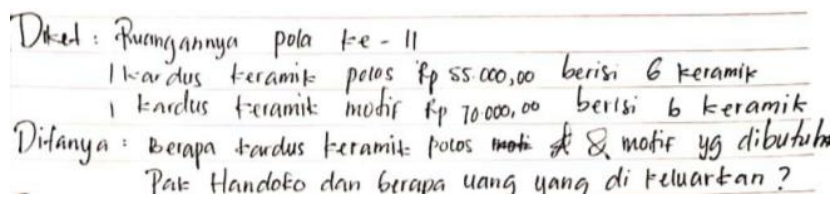

Gambar 4. Lembar jawaban SE tahap memahami masalah

Berdasarkan Gambar 4, terlihat bahwa SE menuliskan hal-hal yang diketahui dengan menggunakan kata-kata. SE menuliskan informasi berupa harga keramik polos dan keramik motif per kardus, jumlah keramik dalam satu kardus, serta ruangan bersesuaian dengan pola ke-11. Terdapat informasi pada soal yang tidak dituliskan seperti jumlah keramik polos dan keramik motif pada pola ke 1, 2, dan 3. SE juga menuliskan hal-hal yang ditanyakan pada soal dalam bentuk kata-kata secara lengkap dan benar.

SE pada aspek kelancaran menuliskan informasi secara tidak lancar karena masih terdapat sedikit coretan kesalahan. Sehingga dapat dikatakan bahwa pada tahap memahami masalah, SE mengkomunikasikan dengan akurat, tidak lengkap dan tidak lancar. Sejalan dengan penelitian Satriawan, Budiyono, dan Indriati (2019) bahwa siswa berkepribadian extrovert masih belum menuliskan informasi secara terperinci. Itu akan sangat mempengaruhi keberhasilan siswa dalam mempersiapkan penyelesaian fase selanjutnya.

\section{Membuat rencana}

SE pada tahap membuat rencana tidak menyatakan gambar ke dalam bahasa, simbol, ide, atau model matematika. Selain itu SE juga tidak menuliskan rumus dalam proses penyelesaian masalah ini tetapi langsung pada pengaplikasian rumusnya, sehingga pada tahap membuat rencana dapat dikatakan tidak lengkap, tidak akurat, dan tidak lancar. 


\section{Melaksanakan rencana}

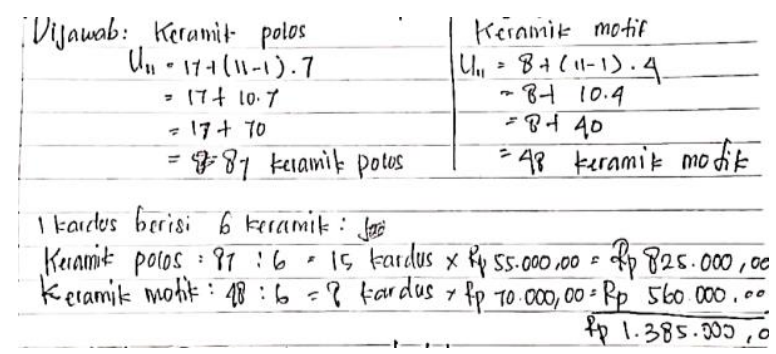

Gambar 5. Lembar jawaban SE tahap melaksanakan rencana

Langkah-langkah yang dilakukan pada tahap melaksanakan rencana sebagai berikut: pertama SE menentukan jumlah keramik polos dan keramik motif dengan menggunakan rumus barisan aritmetika dan didapatkan keramik polos 87 buah dan keramik polos 48 buah. Setelah itu SE menentukan banyaknya kardus keramik polos dan motif dengan membagi jumlah keramik dengan banyak keramik dalam satu kadus. Keramik polos yang dibutuhkan yaitu $\frac{87}{6}=15$ kardus, hasil bagi harusnya 14,5 tetapi karena pada soal dituliskan bahwa pembelian keramik minimal 1 kardus dan tidak boleh mengecer, maka dibulatkan menjadi 15. Keramik motif yang dibutuhkan $\frac{48}{6}=8$ kardus. Langkah selanjutnya menentukan uang yang dikeluarkan dengan cara mengalikan harga masing-masing keramik dengan jumlah kardus keramik polos dan keramik motif. Setelah itu menjumlah uang untuk keramik polos dan keramik motif sehingga total uang yang dikeluarkan yaitu Rp. 1.385.000,00. Berdasarkan uraian tersebut dapat diketahui bahwa SE menuliskan langkahlangkah perhitungan secara lengkap, tidak akurat, dan tidak lancar. Hal ini dapat dilihat dari gambar 6 bahwa untuk menentukan jumlah keramik polos pada pola ke-11 SE menggunakan rumus barisan aritmetika, hal itu dinilai kurang tepat karena beda dari barisan tersebut tidak selalu sama tetapi terus meningkat. Seharusnya untuk menentukan jumlah keramik polos dapat menggunakan barisan aritmetika bertingkat. Hal ini dapat terjadi dikarenakan pada tahap sebelumnya SE tidak menyatakan jumlah keramik polos ke dalam suatu barisan. SE kurang teliti dan sedikit ceroboh dalam menentukan rumus yang digunakan untuk menentukan jumlah keramik polos. Hal ini selaras dengan pendapat Jazuli dan Lathifah (2018) bahwa karakteristik orang yang berkepribadian extrovert saat mengerjakan sesuatu biasanya dilakukan dengan cepat walaupun tidak sempurna dan kadang bertindak ceroboh. 


\section{Memeriksa kembali}

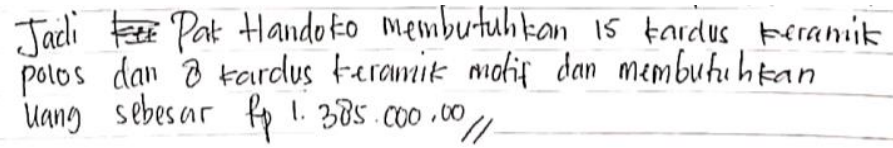

Gambar 6. Lembar jawaban SE tahap memeriksa Kembali

SE pada tahap memeriksa kembali menuliskan kesimpulan dengan lengkap tetapi kurang tepat yaitu pada jumlah keramik polos yang dibutuhkan dan jumlah uang yang dibutuhkan untuk membayar keramik. Hal ini dikarenakan ada kesalahan pada saat menuliskan langkah-langkah penyelesaian masalah. Sedangkan untuk aspek kelancaran, masih terdapat coretan kesalahan saat menuliskan kesimpulan. Sehingga dapat dikatakan bahwa dalam memeriksa kembali SE mengomunikasikan dengan lengkap, tidak akurat, dan tidak lancar. Hal ini sesuai dengan penelitian Septiana, Kusmayati, dan Fitriana (2018) bahwa siswa kepribadian extrovert menuliskan hasil akhir atau kesimpulan dari pekerjaan meskipun hasilnya tidak tepat.

Komunikasi matematika tulis antara subjek introvert dan extrovert memiliki beberapa perbedaan, sebagaimana disajikan dalam Tabel 2 berikut ini.

Tabel 2. Perbedaan profil komunikasi matematika tulis subjek introvert dan extrovert

\begin{tabular}{|c|c|c|c|}
\hline No & $\begin{array}{c}\text { Langkah- } \\
\text { langkah Polya }\end{array}$ & Subjek Introvert & Subjek Extrovert \\
\hline 1 & $\begin{array}{l}\text { Memahami } \\
\text { masalah }\end{array}$ & $\begin{array}{l}\text { Menuliskan hal-hal yang diketahui dan } \\
\text { ditanya secara akurat, lengkap, tetapi } \\
\text { tidak lancar. }\end{array}$ & $\begin{array}{l}\text { Menuliskan hal-hal yang diketahui dan } \\
\text { ditanya secara akurat, tidak lengkap, } \\
\text { dan tidak lancar. }\end{array}$ \\
\hline \multirow[t]{2}{*}{2} & $\begin{array}{l}\text { Membuat } \\
\text { rencana }\end{array}$ & $\begin{array}{l}\text { Menyatakan gambar ke dalam suatu } \\
\text { barisan aritmetika dan barisan } \\
\text { aritmetika bertingkat secara akurat, } \\
\text { lengkap, dan tidak lancar. }\end{array}$ & $\begin{array}{l}\text { Tidak menyatakan gambar ke dalam } \\
\text { bahasa, simbol, ide, atau model } \\
\text { matematika. }\end{array}$ \\
\hline & & $\begin{array}{l}\text { Menuliskan aturan secara akurat, } \\
\text { lengkap, dan lancar. }\end{array}$ & $\begin{array}{l}\text { Menuliskan aturan secara tidak } \\
\text { lengkap, tidak akurat, dan tidak lancar. }\end{array}$ \\
\hline 3 & $\begin{array}{l}\text { Melaksanakan } \\
\text { Rencana }\end{array}$ & $\begin{array}{l}\text { Menuliskan langkah-langkah } \\
\text { perhitungan dari awal sampai akhir } \\
\text { secara runtut, akurat, lengkap, tetapi } \\
\text { tidak lancar. }\end{array}$ & $\begin{array}{l}\text { Menuliskan langkah-langkah } \\
\text { perhitungan dengan lengkap, tidak } \\
\text { akurat, dan tidak lancar. }\end{array}$ \\
\hline 4 & $\begin{array}{l}\text { Memeriksa } \\
\text { Kembali }\end{array}$ & Tidak menuliskan kesimpulan. & $\begin{array}{l}\text { Menuliskan kesimpulan secara lengkap, } \\
\text { tetapi tidak akurat, dan tidak lancar. }\end{array}$ \\
\hline
\end{tabular}

Berdasarkan Tabel 2, terlihat bahwa komunikasi matematika tulis siswa introvert lebih baik dari pada siswa extrovert. Hal ini dapat terjadi karena seorang introvert dalam mengerjakan sesuatu dipikirkan secara matang sehingga dilakukan secara hati-hati dengan penuh ketelitian. Sedangkan seorang extrovert dalam mengerjakan sesuatu, dilakukan secara cepat meskipun rentan adanya kesalahan. Sebagaimana menurut Jazuli \& Lathifah (2018) 
seorang introvert saat mengerjakan sesuatu melakukan dengan hati-hati serta teliti sedangkan extrovert dilakukan lebih cepat dengan hasil yang tidak sempurna dan kadang ceroboh. Sebaliknya penelitian ini bertentangan dengan penelitian yang terdahulu yang dilakukan oleh Septiana, Kusmayati, \& Fitriana (2018) yang menyatakan bahwa kemampuan komunikasi matematika siswa berkepribadian extrovert lebih baik daripada siswa berkepribadian introvert. Hal ini terjadi karena pada penelitian Septiana, Kusmayati, \& Fitriana (2018) subjek yang digunakan memiliki kemampuan matematika yang heterogen sehingga jika terdapat perbedaan dalam mengkomunikasikan pemikirannya dimungkinkan karena adanya perbedaan kemampuan matematika tersebut. Lebih lanjut Lester D. Crow \& Alice Crow (dalam Susanti, 2016) menyatakan bahwa salah satu karakteristik introvert yaitu lebih baik dalam hal tulis menulis daripada berbicara, sedangkan extrovert lebih fasih dalam berbicara.

\section{SIMPULAN DAN SARAN}

Siswa introvert memenuhi keakuratan dan kelengkapan komunikasi matematika tulis pada tahap memahami masalah, membuat rencana, dan melaksanakan rencana, tetapi tidak memenuhi keakuratan dan kelengkapan pada tahap memeriksa kembali,sedangkan siswa extrovert memenuhi keakuratan komunikasi matematika tulis hanya pada tahap memahami masalah. Selain itu, siswa extrovert juga memenuhi aspek kelengkapan komunikasi matematika tulis pada tahap melaksanakan rencana dan memeriksa kembali. Siswa introvert dan extrovert tidak memenuhi aspek kelancaran komunikasi matematika tulis.

Penelitian ini hanya dilakukan pada siswa perempuan. Untuk itu diharapkan bagi peneliti selanjutnya dapat mengkaji subjek berjenis kelamin laki-laki. Disarankan juga untuk meninjaunya berdasarkan faktor lain. Selain itu, untuk penelitian selanjutnya, perlu dilakukan wawancara sehingga data yang sudah didapatkan dari tes tulis lebih akurat dan jelas, karena jika tidak diklarifikasi ke subjek dimungkinkan terjadi perbedaan persepsi antara subjek dengan peneliti misal dalam memahami notasi dan simbol.

\section{DAFTAR RUJUKAN}

Asmana, A. T. (2018). Profil Komunikasi Matematika Tertulis dalam Pemecahan Masalah Matematika di SMP Ditinjau dari Kemampuan Matematika. Inspiramatika Jurnal Inovasi Pendidikan dan Pembelajaran Matematika, 1-12.

Izzati, N., \& Suryadi, D. (2010). Komunikasi Matematik dan Pendidikan Matematika Realistik . Seminar Nasional Matematika dan Pendidikan Matematika, (hal. 721-729). 
Yogyakarta.

Jazuli, A., \& Lathifah, M. (2018). Deskripsi kemampuan Pemecahan Masalah Matematika Pada Soal Cerita Berdasarkan Tipe Kepribadian Ekstrovert - Introvert Siswa SMP Negeri 8 Rembang. AlphaMath Journal of Mathematics Education, 23-32.

Kurnila, V. S., Jau, M. A., Fedi, S., \& Kurniawan, Y. (2018). Pemecahan Masalah dengan Pendekatan Saintifik dan Koperatif Tipe NHT, serta Peningkatan Kemampuan Komunikasi Matematika Siswa SMP. JRPM (Jurnal Review Pembelajaran Matematika), 3(2), 132-145.

Mahmudi, A. (2009). Komunikasi dalam Pembelajaran Matematika. Jurnal MIPA MIPA UNHALU.

Miles, M. B., Huberman, A. M., \& Saldana, J. (2014). Qualitative Data Analysis: A Methods Sourcebook. United States of Amerika: Sage Publications.

NCTM. (2000). Principles and Standars for School Mathematics. United States of Amerika: NCTM.

Noviani, J. (2016). Profil Berpikir Metaforis (Metaphorical Thingking) Siswa SMP dalam Memecabkan Masalah Aljabar Ditinjau dari Tipe Kepribadian. Surabaya: PPs Universitas Negeri Surabaya.

Ontario Ministry of Education. (2005). The Ontario Curriculum 1-8 Mathematics. Ontario: Queen's Printer for Ontario.

Polya, G. (1973). How to Solve It A New Aspect of Mathematical Method. New Jersey: Princeton University Press.

Satriawan, H., Budiyono, \& Indriati, D. (2019). The Mathematical Communication Process of Extrovert Introverted Students in Solving the Contextual Mathematics. Proceedings of the 2nd International Conference on Education (hal. 492-499). Purwokerto: EAI Research Meets Inovation.

Septiana, A. C., Kusmayati, T. A., \& Fitriana, L. (2018). Mathematical Communication Skill of Senior High SChool Student Based on Their Personality Types. Journal of Physics: Conference Series. Dipetik Februari 14, 2020

Siswono, T. Y. (2008). Model Pembelajaran Matematika Berbasis Pengajuan dan Pemecahan Masalah Untuk. Meningkatkan Kemampuan Berpikir Kreatif. Surabaya: Unesa University Press.

Sumarmo, U. (2012). Pendidikan Karakter Serta Pengembangan Berpikir dan Disposisi Matematik Dalam Pembelajaran Matematika. Seminar pendidikan Matematika, (hal. 123). NTT.

Suryabrata, S. (2011). Psikologi Kepribadian. Jakarta: PT RAJAGRAFINDO PERSADA.

Susanti, S. W. (2016). Identifikasi Kemampuan Berpikir Matematika Rigor Siswa Tipe Kepribadian Introvert Ekstrovert dalam Menyelesaikan Soal Matematika. PRISMA, Prosiding Seminar Nasional Matematika, (hal. 308-316).

Swasti, M., Maimunah, \& Roza, Y. (2020). Analisis kemampuan komunikasi matematis siswa kelas viii smp pada materi pola dan barisan bilangan. MATH DIDACTIC: JURNAL PENDIDIKAN MATEMATIKA, 6, 169 - 182. 